\title{
Tożsamościowe roz-poznania. Doświadczenia Zagłady na wsi
}

Karolina Koprowska 


\section{Tożsamościowe roz-poznania. Doświadczenia Zagłady na wsi}

Karolina Koprowska

TEKSTY DRUGIE 2017, NR 6, S. 250-264

DOI: 10.18318/td.2017.6.15

\section{Wprowadzenie}

Punktem wyjścia do rozważenia problemu tożsamościowych roz-poznań na wsi jest sformułowane przez Wojciecha Józefa Bursztę stwierdzenie, że okres II wojny światowej - podczas którego zagrożenie egzystencji wsi zostało skonfrontowane z Zagładą jej „najbliższych obcych", czyli Żydów - był dla wsi sprawdzianem własnej tożsamości'. Rezultat tego sprawdzianu można rozpatrywać przynajmniej w trzech następujących aspektach: 1) zgładzenie kultury żydowskiej wyznacza początek „kresu kultury chłopskiej”, 2) doświadczenie Zagłady obnaża niewspółmierność modeli tożsamościowych wsi - empirycznego i wyobrażeniowego (nieustannie mityzowanego obrazu wsi), 3) chłopska postawa wobec żydowskiej śmierci ujawnia moralną dwuznaczność.

1 Zob. W.J. Burszta Struktury trwania. Kultura chłopska i jej determinanty, w: Zarys krajobrazu. Wieś polska wobec Zagłady Żydów 1942-1945, red. B. Engelking, J. Grabowski, Stowarzyszenie Centrum Badań nad Zagładą Żydów, Warszawa 2011, s. 53-55.

Karolina Koprowska

- magister filologii polskiej o specjalności antropologiczno-kulturowej oraz studentka judaistyki w ramach Międzywydziałowych Indywidualnych Studiów Humanistycznych UJ. Stypendystka Ministerstwa Nauki i Szkolnictwa Wyższego. Współautorka książki Szczekociny wopowieściach mieszkańców. Czasy przedwojenne i wojna i redaktorka monografii Wieś: miejsce, doświadczenie, opowieść. 
Kwestia rozpoznań tożsamościowych na wsi, formułowanych wobec Zagłady, implikuje zatem nie tylko perspektywę chłopską (i problem identyfikowania się chłopa jako ofiary/sprawcy/sąsiada), ale również żydowską. Charakterystyczne dla Zagłady na wsi, zwłaszcza dla jej trzeciego etapu ${ }^{2}$, jest bowiem splątanie szczególnie dwóch losów: polskiego (chłopskiego) i żydowskiego. W Złotych żniwach Jan Tomasz Gross zwraca uwagę, że „obrzeża Holokaustu” miały decydujące znaczenie dla losu żydowskiego, gdyż jedyna droga ocalenia dla Żydów prowadziła poprzez kontakt z ludnością miejscową. Podejmowane przez polskich chłopów decyzje zyskiwały wówczas większą siłę sprawczą i wpływały w pewnym stopniu na bieg zdarzeń'. Zmniejszeniu dystansu między Żydami a wiejską wspólnotą oraz większej decyzyjności chłopów co do losów ukrywających się w okolicy Żydów sprzyjał specyficzny status Niemców jako nadrzędnej instancji władzy okupacyjnej, ale zwykle na wsi nieobecnej, co potwierdzają obserwacje zanotowane w relacjach zarówno chłopów, jak i ukrywających się na wsiach Żydów: „Gdyby nie Polacy, moglibyśmy spokojnie przeżyć ten krytyczny czas, bo Niemcy nie pokazywali się po wsiach" ", „We wsi mało widziano Niemców. Częste zarządzenia ukazywały, że jesteśmy pod zaborem"s. Piętrzenie zależności i natężenie emocji, wynikające z bliskości relacji polsko-żydowskich, powodowało tworzenie się

2 Zob. B. Engelking Jest taki piękny słoneczny dzień... Losy Żydów szukających ratunku na wsi polskiej 1942-1945, Stowarzyszenie Centrum Badań nad Zagładą Żydów, Warszawa 2011, s. 25-27. Por. J. Grabowski Judenjagd. Polowanie na Żydów 1942-1945. Studium dziejów pewnego powiatu, Stowarzyszenie Centrum Badań nad Zagładą Żydów, Warszawa 2011. W procesie eksterminacji Żydów, dokonywanym przez Niemców na terenach Generalnego Gubernatorstwa, wyróżnia się trzy etapy: 1. eksterminację pośrednią - koncentrowanie i wyniszczanie Żydów w gettach głodem; 2. eksterminację bezpośrednią - mordowanie Żydów w obozach zagłady, które prowadzono pod kryptonimem akcji Reinhardt; 3. Judenjagd, czyli "polowanie na Żydów” - za pomocą takiego określenia Niemcy nazywali akcję poszukiwania i mordowania ocalałych w latach 1942-1945. Ten etap określa się też często mianem "trzeciej fali Holokaustu”. Akcję Judenjagd można dodatkowo podzielić na dwie fazy. Pierwsza trwała kilka lub kilkanaście dni po akcjach wysiedleńczych, kiedy Niemcy systematycznie wyłapywali osoby ukrywające się na terenie opuszczonych gett i w ich pobliżu. W drugiej fazie, trwającej w zasadzie do końca wojny, tropiono, łapano i mordowano wszystkich ukrywających się jeszcze Żydów. W tej ostatniej fazie Niemcy szczególnie korzystali z pomocy granatowej policji oraz mieszkańców okolicznych wsi czy miasteczek.

3 Zob. J.T. Gross (współpraca I. Grudzińska-Gross) Złote żniwa, Znak, Kraków 2011, s. 115.

4 Cyt. za: B. Engelking, Jest taki piękny słoneczny dzień..., s. 132.

5 K. Kersten, T. Szarota Wieś polska 1939-1948, t. 2, PWN, Warszawa 1967-1977, nr relacji 184 (1424), s. 256. 
wieloczłonowej konfiguracji relacji i postaw wobec doświadczenia Zagłady, w które każdy na różnym poziomie zaangażowania był w jakiś sposób uwikłany, nie mógł pozostać bezstronny ${ }^{6}$.

Problemowi identyfikowania siebie w odniesieniu do doświadczenia granicznego chciałabym przyjrzeć się przez pryzmat dwóch bliskich sobie narracji: wojennego dziennika Melanii Weissenberg, dziewczynki ukrywającej się u polskiego gospodarza, oraz prowadzonej z punktu widzenia dziecka narracji literackiej Tadeusza Nowaka. Choć przekazywane przez oboje autorów doświadczenia są niewspółmierne, znaczenie, jakie zyskują ich relacje, wydaje się podobne - zarówno dziennik, jak i utwory Nowaka powstają w odpowiedzi na konieczność przepracowania osobistego uwikłania w Zagładę, stanowią wyraz poszukiwań własnego idiomu do wyrażenia problematyczności tego doświadczenia. Zapisy te łączy ponadto niesamowita bliskość, której rewersem okazuje się doświadczeniowe oddalenie. Po pierwsze, jest to bliskość pokoleniowa - Weissenberg i Nowak są rówieśnikami, oboje urodzili się w 1930 roku - podstawowa dla ich postrzegania jest zatem perspektywa dziecięca. Po drugie, bliskość miejsca i okolicy - wydarzenia opisywane przez Nowaka i Weissenberg rozgrywają się w pobliżu Dąbrowy Tarnowskiej (dystans dzielący rodzinną miejscowość Nowaka i wieś, w której ukrywała się Weissenberg, to zaledwie $15 \mathrm{~km}$ ). Obie relacje, choć dzielą je odmienne doświadczenia, odwołują się zatem do tego samego kontekstu lokalnego. Jak wynika z badań Jana Grabowskiego, opublikowanych w szczegółowym opracowaniu Judenjagd. Polowanie na Żydów 1942-1945, teren powiatu Dąbrowa Tarnowska, położony na wschodzie województwa małopolskiego, miał przed wojną typowo rolniczy charakter. Żydzi mieszkali tu zarówno w miasteczkach, jak i na wsiach, w których prowadzili życie niewiele różniące się od życia sąsiadów chrześcijan?.

6 Niemożność pozostania bezstronnym prowadzi do postronnego uczestniczenia polskich świadków w Zagładzie. Dlatego też na ich określenie posługuję się terminem „postronny” jako tłumaczeniem angielskiego terminu bystanders i jako ekwiwalentem dla nieprecyzyjnej i nieadekwatnej kategorii „świadka”. Postronny jest przede wszystkim tym, który nie jest bezstronny, nie może uchylić się od zaangażowania, nie tyle odnoszącego się do konkretnych działań, ile mającego charakter afektywny i emocjonalny. Postronne uczestnictwo, które jest nie-do-zniesienia, stawia go zatem w moralnie dwuznacznej pozycji wobec cudzego cierpienia. Postronny jest też niemym i milczącym świadkiem - doświadczenie Zagłady pozbawia go zdolności do mówienia bądź nie ma on odpowiedniego języka, który pozwoliłby mu na pojęciowe opanowanie własnych odczuć.

7 Zob. J. Grabowski Judenjagd..., s. 20-21. 
Zestawienie tekstów Weissenberg i Nowaka wynika nie tylko z pożytków konfrontowania różnych perspektyw, ale również z hipotezy znaczenia kategorii „lokalności” do analizy doświadczenia Zagłady na wsi (polskiej prowincji). Lokalność w ujęciu np. Ludwika Stommy czy Antoniny Kłoskowskiej wskazuje przede wszystkim na ukonkretnienie w czasie, miejscu i krajobrazie, z czym wiążą się określone wzorce kulturowe i świadomościowe, które organizują życie społeczne w małej społeczności. Lokalność, powiązana z kulturowymi i społecznymi partykularyzmami, definiuje zakres doświadczeń życiowych jednostki oraz ma znaczenie przy konstruowaniu jej tożsamości ${ }^{8}$.

\section{Formy przetrwania - dziennik Melanii Weissenberg9}

Melania Weissenberg urodziła się w Krakowie w 1930 roku, w rodzinie kupieckiej. Kilka miesięcy po wybuchu wojny rodzina Weissenbergów została wyrzucona ze swojego sklepu i mieszkania. Podjęła wówczas decyzję o znalezieniu schronienia w Dąbrowie Tarnowskiej, u dalszych krewnych. Do września 1942 roku Melania Weissenberg przebywała wraz z rodziną w getcie; tydzień przed drugą akcją likwidacyjną getta dziewczyna wraz ze swoją starszą kuzynką Heleną trafiła do gospodarstwa Wiktora Wójcika i jego siostry (z którymi wcześniej matka Weissenberg nawiązała kontakt). Dziewczyny ukrywały się najpierw w stodole, potem w specjalnie przygotowanej kryjówce - wkopanej w ziemię skrzyni, gdzie spędziły dwa kolejne lata, aż do zakończenia wojny.

Doświadczenie Melanii Weissenberg naznacza fundamentalne zerwanie związane z przeniesieniem się na wieś, a szczególnie z początkiem ukrywania się w ziemi. Cezura ta ma dwojaki charakter - z jednej strony egzystencjalny i tożsamościowy, obejmuje bowiem proces stawania się kobietą i wyznacza akt inicjacyjnego przejścia od (jeszcze) dzieciństwa do (już) dorosłości,

8 Zob. L. Stomma Antropologia kultury wsi polskiej, Wydawnictwo Piotr Dopierała, Łódź 2002. Por. J. Hajduk-Nijakowska Od realności do wirtualności, czyli o sposobach rozumienia lokalności w badaniach kulturowych, "Tematy z Szewskiej” 2012 nr I (7), http://www.tematyzszewskiej. pl/index.php/2016/03/06/od-realnosci-do-wirtualnosci-czyli-o-sposobach-rozumienialokalnosci-w-badaniach-kulturowych/ (06.05.2017). Por. F. Tönnies Wspólnota i stowarzyszenie, przeł. M. Łukasiewicz, PWN, Warszawa 2008.

9 Dziennik Melanii Weissenberg, 1942-1945, W: „Szczęście posiadać dom pod ziemiq̨...” Losy kobiet ocalałych z Zagłady w okolicach Dąbrowy Tarnowskiej, red. naukowa i wstęp J. Grabowski, Stowarzyszenie Centrum Badań nad Zagładą Żydów, Warszawa 2016, s. 44. Cytowane w artykule fragmenty pochodzą z tego wydania. 
a z drugiej - przestrzenny, związany z zawieszeniem między miastem (jako przestrzenią kultury, literatury, a także edukacji i wychowania, w której autorka czuje się zadomowiona) a wsią (identyfikowaną przez Weissenberg z naturą, biologizmem i prymitywizmem - a więc zupełnie obcymi, a nawet pogardzanymi przez nią postawami i wartościami). Trajektoria losu autorki - chybotliwa, zmienna, uniemożliwiająca zdystansowaną obserwację zostaje wpisana w formę dziennika prowadzonego w warunkach naruszanej i kurczącej się stopniowo sfery prywatności (pod względem przestrzennym jej los wyznaczają kolejne miejsca: dom - mieszkanie w getcie - stodoła kryjówka w ziemi). Swój dziennik Melania Weissenberg zaczyna pisać w 1942 roku jako formę odpowiedzi na wydarzenia wojenne i jako strategię radzenia sobie ze stopniową degradacją życia i nieustannym poczuciem zagrożenia.

Zapiski z czasu pobytu w getcie i w pierwszych miesiącach ukrywania się u Wójcika pisane są dosyć regularnie, z wyraźną stylistyczną dbałością i staranną, wręcz literacką polszczyzną. Melania rejestruje wówczas przede wszystkim swoje „życie wewnętrzne” - refleksje, stany emocjonalne, przeżycia duchowe, którym nadaje ton romantyczny i romansowy (będący echem lektury powieści m.in. Marii Rodziewiczówny). 29 kwietnia 1942 roku autorka notuje:

Jakże naiwne były moje myśli! Teraz dopiero to widzę. Ja do tej ostatniej, strasznej Jego chwili myślałam, że jednak jest, to znaczy, że jednak tu, w tym wypadku, okaże się miejsce między ustami a brzegiem pucharu ... [wyróżnienie moje - K.K.] Widzę, że nie ma. (s. 28)

Za pomocą peryfraz i metafor wyraża również swój strach i przeczucie śmierci; wojnę i życie w getcie opisuje jako doświadczenia, które dotykają ją przede wszystkim duchowo i emocjonalnie. Nietrudno zarazem doszukać się w jej dzienniku typowej dla dzienników dziewcząt pensjonarskiej formy aktywowanie znanego wzorca opisu młodzieńczych doświadczeń wyrażałoby zatem paradoksalną próbę oswajania tego, co wymyka się granicom poznania, nie mieści się w ramach jej dotychczasowego doświadczenia.

Dla ukrywającej się pod ziemią autorki dziennik staje się jedynym łącznikiem z dawnym życiem, jego symbolicznym przedłużeniem. W zapisie notatek można jednak zauważyć znaczącą różnicę - nie są one już prowadzone regularnie, język staje się natomiast bardziej „chropowaty”. Literackie określenia zostają zastąpione wyrażeniami z wiejskiej gwary, przejętymi pod wpływem kontaktu z Wójcikiem. Przekształcanie się języka ukazuje m.in. 
następujący fragment: „Drogi, kochany, złoty «wujciu» i ty, nasza Pani słodka! Jakże bezgranicznie wdzięczną Wam jestem, że pomagacie nam pchać tę ciężką tak okropnie taczkę życia, na którą źli ludzie nałożyli takiego ciężaru, że bez was, nie ma rady, na pewno bym nie uciąłła!" (s. 42-43). Transformacja języka opisu koresponduje ze zmianą sposobu opisywania Zagłady, postrzeganą teraz przede wszystkim przez pryzmat granicznych doświadczeń, np. głodu, zimna, nudy czy udręki ukrywania się w kryjówce po ziemią, nazywanej "grobem”. Weissenberg tak opisuje swoją kryjówkę:

Dla wszystkich stworzeń, które żyją, jest miejsce na powierzchni ziemi. Tylko dla dwóch biednych, opuszczonych żyjących istot brakło go niestety na powierzchni ziemi. Więc biedne te nieszczęśliwe istoty ludzkie zmuszone są żyć pod jej powierzchnią, i to w małej skrzynce, ciasnej, w której można leżeć zaledwie, i to trochę skurczonym. [...] Ciasnota, brud, robactwo, ciemno, duszno, jak w grobie. I owe istoty dopiero szczęśliwe, że tak, a nie gorzej, i w codziennej modlitwie dziękują za ten „grób”. [...] Czy nigdy już nieprzeznaczone nam na świat wyjść? (s. 44)

Weissenberg porzuca język duchowych rozterek i refleksyjności, a koncentruje się na fizycznych, fizjologicznych i cielesnych doznaniach, które są dla niej obce. W sposobie ich opisywania stosuje zatem strategię przyswojenia - upodobnienia do swojego „opiekuna”, odczuwania podobnych do jego pragnień i potrzeb.

Autorka wydaje się świadoma splotu emocji, zależności i relacji władzy, jaki łączy ją z pomagającym chłopem ${ }^{10}$; mając świadomość, że jest on dysponentem jej życia, odczuwa przed nim strach, jako ofiara jest bowiem całkowicie od niego zależna. Tę zawikłaną psychologicznie sytuację Weissenberg pośrednio wyraża m.in. w notatce z 25 stycznia 1943 roku, w której wygłasza pochwałę swoich „opiekunów”:

I ciagle prosimy o zdrowie naszych kochanych, dobrych gospodarzy, naszego „wujcia” i naszej pani, żeby do końca wytrwali szczęśliwie w swoim szlachetnym postanowieniu. Żeby im Bóg dodał siły do przecierpienia z nami! Bo przecież ci złoci ludzie czynią dla nas, co tylko w ich mocy i możności. Podziwiam wciąż tę ich wytrwałość, bo przecież to rzecz nie

10 Więcej na temat wizerunku chłopa w relacjach żydowskich zob. B. Engelking Jest taki piękny słoneczny dzień..., s. 131-138. 
lada, a bądź co bądź żadnych zobowiązań wobec nas nie mają, bo nim my do nich przyszli, to nas nawet dobrze nie znali! Czuję, że nieraz bardzo nas nie lubią, bo jesteśmy wszak przyczyną ich strachu i niepokoju, w którym żyją, odkąd my do nich przyszli. Jednak ich idealny charakter nie pozwala im wysłać nas na pewną śmierć i wielka ufność w Boga pozwala im do przezwyciężenia panicznego strachu, który niestety tak często ma miejsce. Drogi, kochany, złoty „wujciu” i ty, nasza Pani słodka! Jakże bezgranicznie wdzięczną Wam jestem, że pomagacie nam pchać tę ciężką tak okropnie taczkę życia, na którą źli ludzie nałożyli takiego ciężaru, że bez was, nie ma rady, na pewno bym nie uciągła! (s. 42-43)

Nieco egzaltowana i hiperbolizowana afirmacja pomocy gospodarza i jego siostry (nazywanych tu przez autorkę „wujciem” i „naszą panią") jest podszyta niepokojem przed zmianą chłopskiego nastawienia do ukrywających się Żydówek, która mogłaby wiązać się nie tylko z pogorszeniem ich położenia, ale także z wypędzeniem z kryjówki lub denuncjacją. Pochwała wydaje się zatem formą zaklinania rzeczywistości, za pomocą której autorka opanowuje swój lęk.

Obraz Wójcika, jaki ujawniają karty dziennika, jest dynamiczny, na co wskazują zmieniające się w zależności od konkretnego kontekstu określenia, którymi autorka nazywa chłopa. Zdrobnienie „wujcio” podkreśla prostoduszny, ufny i zarazem oparty na wdzięczności stosunek dziewczynki do pomagającego, ale też - na poziomie symbolicznym - ma pełnić funkcję dodatkowego potwierdzenia obowiązku udzielenia jej pomocy (w tym przypadku chodziłoby o odwołanie się do wyimaginowanych relacji rodzinnych). W odniesieniu do Wójcika autorka używa również pejoratywnego określenia "huncwot”, które jest performatywną formą zniewagi i buntu; pojawia się ono najczęściej w notatkach rejestrujących pogorszenie się sytuacji dziewcząt z powodu braku opieki Wójcika. Weissenberg zaznacza, że stosunek gospodarza do ukrywających się dziewczą zaczął zmieniać się wraz z przedłużającą się wojną i udręką udzielania pomocy. W notatce z maja 1944 roku znajduje się następujący fragment: „Przyszedł w południe Ciuruniu i powiedział, że Pankowa mówiła, że ma Żydów w stajni. Wobec tego on już nie może dłużej ryzykować, i kazał nam robić, co chcemy. Powiedział, żebyśmy poszły w pola, choć wiedział dobrze, że żyć człowiek w polu nie jest w stanie" (s. 51).

Złożoność tej relacji, opartej na władzy i zależności, podkreśla również inna nazwa - „Ciuruniu” lub „Ciureczku”, mająca podtekst erotyczny. Występuje ona zwłaszcza w opisach stosunków seksualnych autorki i jej kuzynki z Wójcikiem, które Weissenberg koduje w dzienniku jako „lutanie się”. 
Oddanie wybawcy swojego ciała miało gwarantować ocalenie - zarówno poprzez spełnianie „prymitywnych i skromnych pragnień" chłopa (jak pisze Weissenberg"1), jak i przełamanie nudy i monotonii życia pod ziemią. Strategia tożsamościowa, jaką przyjmuje i realizuje Weissenberg, polegałaby zatem na "dywersyjnym przejmowaniu władzy" - na próbie odzyskania do pewnego stopnia własnej sprawczości i możliwości sterowania własnym losem. Weissenberg notuje często, że to ona "sprowokowała Ciurunia" lub namówiła do tego swoją kuzynkę. Pod koniec wojny autorka odnotowuje nawet, że zamierza zaszantażować gospodarza domniemaną ciążą. Seks traktuje więc jako narzędzie manipulacji, które spełnia różne role - jest metodą na przetrwanie, potwierdzaniem własnej podmiotowości, odkrywaniem własnej kobiecości, przełamywaniem nudy, ale także sposobem spełniania własnych (często dziecięcych) zachcianek. Znamiennym przykładem jest tu notatka z 26 lutego 1944 roku: „Ciuruniu uciął łebek mojemu Pontusiowi. A wszystko przez nią, bo mogła temu zapobiec łatwo. Tylko że jej się to wydawało za błahe” (s. 49). Autorka suponuje zatem, że poprzez stosunek seksualny jej kuzynka mogła wymusić na chłopie, aby ten nie zabijał jej ulubionego kogucika. Różne funkcje, jakie Weissenberg przypisuje seksualnej relacji z Wójcikiem, wskazują na swego rodzaju tożsamość liminalną, w której dochodzi do jednoczesnego sprzężenia kobiecości i dziecinności.

\section{Nie przyszło mi do głowy... - spóźnione roz-poznanie Zagłady w twórczości Tadeusza Nowaka}

Problem roz-poznania siebie wobec Zagłady, podejmowany z perspektywy chłopskiego dziecka, jest w twórczości Tadeusza Nowaka powiązany z postacią-figurą Mojżesza, rozpisaną na konkretne warianty (w kilku różnych utworach: wierszu, dwóch opowiadaniach i powieści). Zdaniem Anity Jarzyny, historia żydowskiego bohatera opiera się na „trzech intonacjach jednego imienia"12, wyznaczających proces dorastania Mojżesza: od dziecka, niemow-

11 W tym kontekście wizerunek chłopa dopełnia jeszcze prymitywizm - Weissenberg pisze, kierując swoje słowa do Wójcika: „Niechaj choć po części ziszczą się Twoje tak bardzo prymitywne iskromne pragnienia!".

Zob. A. Jarzyna/ednożydowskie imię, trzy intonacje. Zanim Tadeusz Nowakmógłprzeczytać,Biedni Polacy patrzq na getto"J. Błońskiego, w: Wojna i postpamięć, red. Z. Majchrowski, W. Owczarski, Wydawnictwo Uniwersytetu Gdańskiego, Gdańsk 2011. Por. A. Jarzyna Imaginauci. Pismo wyobraźni w poezji Bolesława Leśmiana, Józefa Czechowicza, Krzysztofa Kamila Baczyńskiego, Tadeusza Nowaka, Universitas, Łódź-Kraków 2017. 
lęcia (w dedykowanym Janowi Błońskiemu wierszu Koszyk wiklinowy z tomu Jasetkowe niebiosa, $1957^{13}$ ), poprzez chłopca, kolegę z ławki szkolnej (w opowiadaniu Mojżesz ze zbioru Przebudzenia, 1962 ${ }^{14}$ ), do dorastającego, młodego chłopaka, klarnecisty z powieści A jak królem... z 1968 roku ${ }^{15}$. Wyliczenie kolejnych wcieleń Mojżesza, proponowane przez Jarzynę, jest jednak niepełne - brakuje w nim bowiem jeszcze jednej dziecięcej postaci Mojżesza, ukazanej na czele pochodu żydowskich widm w tytułowym opowiadaniu zbioru Przebudzenia ${ }^{16}$. Te cztery warianty spaja wspólna rama dialektyczna - ocalenia (na poziomie mitu, opowieści) i nieocalenia (w planie rzeczywistym) głównego bohatera. Dysonans tych dwóch planów w wierszu Koszyk wiklinowy wiąże się z powtarzającą formułą „nie przyszło mi do głowy”, wskazującą na „spóźnione rozpoznanie" własnego uwikłania w Zagładę poprzez zajmowanie pozycji postronnego. Wiersz brzmi następująco:

Mojżesza uratowano w koszyku wiklinowym oblanym smoła

Nie przyszło mi do głowy, musiano mi powiedzieć, że koszyk wiklinowy zamieni w łódkę - dziegieć.

Ogromna zieleń - rzeka łuszczy się. Krew rozlana z otwartej czaszki ścieka na wbite w piach kolana.

Nie przyszło mi do głowy. Po tobie jest jarmułka i talerzyk cynowy, i drewniana kukułka.

T. Nowak Koszyk wiklinowy, w: Jasełkowe niebiosa, PIW, Warszawa 1957. T. Nowak Mojżesz, w: Przebudzenia, Wydawnictwo Literackie, Kraków 1962 (dalej stosuję skrót M). 
Nie przyszło mi do głowy.

Ogromna zieleń - rzeka

przy twarzy oliwkowej

łuszczy się i narzeka.

Zgnił koszyk wiklinowy,

rozlano nocy dziegieć.

Nie przyszło mi do głowy,

nie chciano mi powiedzieć.

Doświadczenie chłopskiego postronnego w formie „spóźnionego rozpoznania" zawiera się w tworzących wierszową klamrę wersach: początkowym - „Nie przyszło mi do głowy, / musiano mi powiedzieć”, oraz końcowym - „Nie przyszło mi do głowy, / nie chciano mi powiedzieć”. „Spóźnione rozpoznanie" Zagłady, czynione z perspektywy czasu, opiera się zatem na dwojakiej perspektywie: zarazem dziecka (empatycznie odczuwającego tragiczny los żydowskich mieszkańców, zwłaszcza szkolnego kolegi, Mojżesza, powracającego w innych utworach poety) i dorosłego (dysponującego wiedzą i świadomością Zagłady). Niezgodność planów poznawczych ujawnia przede wszystkim kontrastowe zestawienie wiersza, ukazującego w szczątkowych obrazach, plamach barw i materialnych śladach-pamiątkach obecności (jarmułce, talerzyku cynowym i drewnianej kukułce) śmierć żydowskiego dziecka, i poprzedzającego utwór zdania-wyjaśnienia, które stwierdza i zapowiada ocalenie. W zakończeniu opowiadania Mojżesz śmierć żydowskiego chłopca jest natomiast kodowana za pomocą rozbieżnych opowieści i pogłosek, usłyszanych przez dziecięcego narratora:

Bo na wiosnę, kiedy wodne młyny mełły coraz więcej zieleni u rzeki, odszedł od nas Mojżesz. Nikt go odtąd nie widział. Jedni powiadali, że go zastrzelono w miasteczku na odpuście, kiedy za karmelka chciał sprzedać drewnianą kukułkę. Inni znów mówili, że pijany żandarm wgniótł go w piach butami. Inni jeszcze szeptali, że Mojżeszowi pomieszało się w głowie, nasmołował wiklinowy koszyk, wyścielił go sianem, i wiosłując rękami, w dół rzeki popłynął. (M, s. 101)

Dziecięcy narrator nie zostaje więc dopuszczony do prawdy, włączony w zbiorowe milczenie pozostaje bez konkretnej wiedzy, lecz z przeczuciem 
śmierci dokonywanej przez nienazwane siły zła, śmierci abstrakcyjnej, która jest trudna do przyjęcia. Piotr Matywiecki zauważa, że okoliczności śmierci Żyda, których nie chciano przekazać dziecięcemu podmiotowi, nie zostały włączone w ustną tradycję opowiadania: „Chłopiec nie odczuł zatem ludowej «biblijności» tego zabójstwa, a objaśnienie biblijne z początku wiersza może dodać dopiero dorosły poeta po wojnie. Nie było zatem możliwości uratowania owego człowieka w realnym życiu i nie było możliwości ratunku symbolicznego, poprzez zbiorową tradycję wsi"17. Śmierć żydowskiego dziecka zostaje więc przemilczana na poziomie pamięci zbiorowej i wyparta z kolektywnej świadomości, nie zostaje również wypowiedziana w wierszu Nowaka. Akt przemocy i zabójstwa pozostaje poza granicami języka i poznania. Podkreśla to - jak stwierdza także Matywiecki - całkowite odosobnienie i samotność ofiary, jej śmierci towarzyszy jedynie narzekanie i opłakiwanie rzecznej wody.

Podwójną perspektywę widzenia Zagłady można również odczytywać inaczej niż w proponowanej przez Matywieckiego interpretacji. Otóż, napięcie między dwiema rozbieżnymi perspektywami dotyczy nie tylko relacji zewnętrznej - między dzieckiem, konfrontującym się z „widokiem cudzego cierpienia", a dorosłymi, którzy zamiast prawdy o śmierci przekazują dziecku ludową wersję biblijnej historii ocalenia Mojżesza w wiklinowym koszyku. Wydaje się, że podmiot wiersza Nowaka reaktywuje sposób postrzegania wydarzeń, jaki był mu dostępny w okresie dzieciństwa, i jednocześnie dopełnia go i kontrapunktuje własną świadomością dorosłego. Dlatego też "spóźnione rozpoznanie" łączy się z odczuciem Freudowskiej „nie-samowitości" - doświadczenie dziecka, które zostało wówczas sformatowane w postaci symbolicznej i mitycznej opowieści o ocaleniu, okazuje się bowiem pod wpływem wiedzy post factum - nie tyle nieznane, ile nie-do-pojęcia; klasyfikuje się jako przeżycie, wobec którego podmiot pozostaje całkowicie bezradny.

Doświadczenie „spóźnionego rozpoznania” ma dla dziecięcego podmiotu utworów Nowaka wymiar traumatyczny. Traumę Cathy Caruth określa „jako reakcję na niespodziewane, przytłaczające i nagłe zdarzenie albo zdarzenia, których nie sposób w pełni uchwycić, kiedy się wydarzają". W traumatyczne doświadczenie jest zatem wpisany paradoks jednoczesnego widzenia i nierozpoznania: „najbardziej bezpośredniemu widzeniu pełnego

17 P. Matywiecki Część II: 1945-1968, Poezja, w: Literatura polska wobec Zagłady (1939-1968), red.

S. Buryła, D. Krawczyńska, J. Leociak, Wydawnictwo IBL PAN, Warszawa 2012, s. 321. 
przemocy wydarzenia może towarzyszyć całkowita niemożność jego (roz) poznania"18. Ulrich Baer, opierający się na koncepcji Caruth w swoich analizach fotografii, działanie traumy ujmuje tak: „Trauma narzuca się poza zasięgiem naszego rozumienia. Spotkanie z rzeczywistością uwzględnia możliwość traumy, wyłania się zatem jako coś, co może pominąć doświadczenie, a jednak zapisać się z wielką siłą na ciele i umyśle jednostki"19. Mechanizm ten zdaje się ukazywać szczególnie fragment opowiadania Mojżesz, który lokuje nadrealizującą, utrzymaną w mityczno-metaforycznym idiomie opowieść ocalenia w konkretnym miejscu i czasie - podczas likwidacji getta tarnowskiego:

Mojżesz żuł listek szczawiowy. W kącikach jego ust pojawiła się zieleń. A ponieważ oczy miał zielone, wydawało mi się, że jest takim małym śpiewającym kalinowym krzewem. Zacząłem się uśmiechać. Wiedziałem, że jeśli dłużej będę patrzył na niego, zacznę coraz głośniej chichotać. Odwróciłem głowę w stronę rzeki. Tuż przy brzegu żółtą jak kobyle mleko wodą płynęli wrzuceni do rzeki rozstrzelani Żydzi. Od czasu do czasu nad wodą błyszczała naszyta na ich plecach żółta jak wiosenna woda rzeki gwiazda. Bałem się poruszyć. Tam u góry rzeki w tarnowskim getcie byli rodzice Mojżesza. (M, s. 98)

W utworach dotyczących Zagłady lokalnej społeczności żydowskiej Nowak przyjmuje określoną strategię - próbuje mianowicie zapisać „traumatyczne przebudzenie" podmiotu, który odczuwa moralną niejednoznaczność własnego doświadczenia bycia postronnym. W oparciu o Lacanowską reinterpretację snu ojca o płonącym dziecku opisanego przez Freuda, Caruth definiuje "traumatyczne przebudzenie” jako próbę zareagowania na „wezwanie, które da się słyszeć wyłącznie we śnie", paradoks konieczności i niemożności konfrontacji ze śmiercią. Jak podkreśla badaczka:

Przebudzić się znaczy tu tyle, co przebudzić się tylko po to, by doświadczyć powtórzenia wcześniejszej porażki. Siła traumy bierze się zatem nie tylko z samej śmierci, ale z tego, że choć ojciec kochał dziecko, nie był w stanie stać się świadkiem jego śmierci. W interpretacji Lacana tego logia studiów nad traumą, red. T. Łysak, Universitas, Kraków 2015, s. 31-32. 
marzenia sennego przebudzenie staje się miejscem traumy, traumy konieczności i niemożności reakcji na śmierć drugiej osoby. ${ }^{20}$

Odnosząc znaczenie „traumatycznego przebudzenia” do sytuacji postronnego Zagłady na wsi, można stwierdzić, że Nowak diagnozuje porażkę świadkowania, która w momencie przebudzenia („spóźnionego rozpoznania”) stała się dla podmiotu utworów poety źródłem traumy. Być może wyraża on również - jak suponował Lawrence L. Langer - niemożność przygotowania "niemych świadków” do adekwatnych reakcji na niebezpieczeństwo zagrażające innym, nie im samym²1.

W kontekście „traumatycznego przebudzenia” postronnego uczestnika Zagłady inne znaczenie przyjmuje opowieść o biblijnym Mojżeszu, przekazana dziecięcemu podmiotowi. Tak jak sen ojca, analizowany przez Freuda i Lacana, opowieść staje się rodzajem wezwania do przebudzenia i kolejnych repetycji mających na celu nieudane próby poradzenia sobie z tym doświadczeniem. Przedmiotem twórczości Nowaka jest więc nie tyle samo doświadczenie Zagłady, ile problem świadomościowego rozpoznania przez postronnych problematyczności własnego stanowiska wobec masowej śmierci. Poeta ujmuje go retroaktywnie i wpisuje w wypracowaną przez siebie poetykę baśniowego, mitycznego i opartego na metaforach obrazowania. Taki zapośredniczony sposób opowiadania o Zagładzie, który przenosi akcent z pojęć na obrazy, traktuję jako rodzaj (prze)milczenia afektywnego, niewskazującego na zatajenie, lecz wyrażającego proces usilnych poszukiwań adekwatnego sposobu wyrażenia niewyrażalnego. Doświadczenie Zagłady u Nowaka zostaje przekazane na innym niż literalny poziomie: w pęknięciach pomiędzy poszczególnymi obrazami, jukstapozycjach czy metaforycznych splotach i emblematycznych figurach-symbolach, zatrzymujących opowieść na granicy przedwyrażalności.

W kontekście „spóźnionego rozpoznania” i retroaktywnego konceptualizowania własnej tożsamości jako postronnego Zagłady mit zdaje się ujawniać niewystarczalność swoich funkcji kompensacyjnych, wyjaśniających i konsolidujących wspólnotę, które w prozie Nowaka tworzą obraz wsi jako mikrokosmosu odzwierciedlającego porządek wszechświata (D. Siwor) ${ }^{22}$, a także

\footnotetext{
C. Caruth Traumatyczne przebudzenia..., s. 40.

Zob. L.L. Langer Świadectwa Zagłady w rumowisku pamięci, przeł. M. Szuster, Wydawnictwo ŻIH, Warszawa 2015, s. 44.

Zob. D. Siwor W kręgu mitu, magii i rytuału. O prozie Tadeusza Nowaka, Universitas, Kraków 2002, s. 139.
} 
„autarkicznego" modelu kultury, który zapewnia narzędzia do pojęciowego opanowania świata (P. Czapliński) ${ }^{23}$. W utworach odwołujących się do doświadczenia Zagłady Nowak konfrontuje mityczno-symboliczną tradycję wsi, proponującą przednowoczesną wizję świata, z Zagładą, której imaginarium ma w dużej mierze rodowód nowoczesny (w opowiadaniu pojawiają się dwa znaki nowoczesności - maszynka do strzyżenia oraz drut, z którego dzieci skręcają zabawki). Wojna i wkraczająca wraz z nią nowoczesność tworzą sytuację konfliktową prowadzącą do zachwiania status quo wiejskiej wspólnoty. Dezintegracja wsi i relacji wspólnotowych wyprzedza zmianę porządku symbolicznego i narracji, która mogłaby wyjaśnić dziejące się transformacje. Porządek zdarzeniowy i realny przynosi więc nieodwracalne zerwanie ze światem przednowoczesnym, podczas gdy na poziomie tradycji obserwujemy jej trwanie. Świadomość chłopska podlega tym samym swego rodzaju rozproszeniu, a w zasadzie zaczyna funkcjonować w schizofrenicznym zawieszeniu. Powracająca w twórczości Nowaka historia Mojżesza, która aktualizuje jednocześnie opozycyjne scenariusze losów chłopca: ocalenia i śmierci, ukazuje fundamentalne pęknięcie między tym, co realne (konfrontacją ze śmiercią) a tym, co symboliczne (prototypową opowieścią o biblijnym Mojżeszu, która zakłada jedynie optymistyczny bieg zdarzeń). Twórczość Nowaka, skupiająca się przede wszystkim na doświadczeniu „traumatycznego przebudzenia”, nie prowadzi do poznania śmierci, widzenia, które przynosi zrozumienie, ale rejestruje sam „akt przebudzenia się", jak pisze Caruth - niedostępne dla siebie widzenie przekazuje innemu i innej przyszłości ${ }^{24}$.

\section{Podsumowanie}

Niesamowita bliskość, która opisuje sprzężenie dwóch losów, polskiego i żydowskiego, podczas Zagłady, ewokuje konieczność postawienia pytania o własną tożsamość, związanego z pozycją zajmowaną wobec doświadczenia granicznego. Zestawienie odmiennych relacji Melanii Weissenberg i Tadeusza Nowaka - ich swoiste zbliżenie - pozwala dwojako sprofilować problem identyfikowania siebie wobec doświadczenia Zagłady, a w szczególności w odniesieniu do wizerunku innego/obcego (żydowskiego kolegi

23 Zob. P. Czapliński Przemieszczenia. O powojennej prozie chłopskiej, w: Migracyjna pamięć, wspólnota, tożsamość, red. R. Sendyka, T. Sapota, R. Nycz, Wydawnictwo IBL PAN, Warszawa 2016, s. 194.

Zob. C. Caruth Traumatyczne przebudzenia..., s. 56. 
szkolnego w przypadku Nowaka, a chłopskiego „opiekuna” w relacji Weissenberg). Z jednej strony wiąże się on z tworzeniem tożsamości tymczasowej, „kryzysowej”, wyrażającej sprzeciw wobec statusu ofiary oraz nakierowanej na utrzymanie własnej podmiotowości i sprawczości (Melania Weissenberg), a z drugiej - tożsamości opartej na „spóźnionym rozpoznaniu” postronnego, który przestaje być obojętny i niezaangażowany wobec Zagłady (Tadeusz Nowak). W obu przypadkach tożsamościowe roz-poznania opierają się na momencie zerwania i nieciągłości - nie dają się jednoznacznie wpisać w role, które wyznaczał zagładowy scenariusz, co więcej: ukazują one próbę ich przekroczenia. Wydaje się, że pisanie - prowadzenie dziennika hic et nunc, a także retroaktywne ujmowanie własnego doświadczenia w formę literacką - pozwala Weissenberg i Nowakowi nie tylko mierzyć się z własnym przeżyciem, ale przede wszystkim kontestować rolę narzuconą przez pochodzenie czy miejsce urodzenia.

\section{Abstract}

\section{Karolina Koprowska}

JAGIELLONIAN UNIVERSITY (CRACOW)

Identity Matters: The Experience of the Shoah in the Village

This article deals with the experience of the Shoah in the countryside as described from two perspectives - Jewish (victim) and Polish (bystander-witness). A key question is how identity is conceptualized in the face of liminal experience in two narratives, namely Tadeusz Nowak's work belonging to the so-called peasant tradition in Polish literature, as well as the diary of Melania Weissenberg, a Jew who hid in a village. These different narratives are linked above all by the place, as both are set in the vicinity of Dąbrowa Tarnowska. Koprowska discusses the works of Nowak and Weissenberg as examples of literary responses to the Shoah in a local village context.

\section{Keywords}

village, Shoah, Tadeusz Nowak, Melania Weissenberg, bystander 